Agnieszika Matusiak

Uniwersytet Wrocławski

\title{
REFLEKSJE O NARRACJI DONBASKIEJ W KULTURZE I LITERATURZE UKRAIŃSKIEJ Z PERSPEKTYWY XXI WIEKU
}

Тревожная штука эта наша современность. Но жить в ней можно и даже нужно. Потому хотя бы, что прожить наши жизни за нас некому. Да и потом, как известно, времена не выбирают.

Владимир Рафеенко ${ }^{1}$

Война - это смерть, смерть, смерть и еще раз смерть. Это не футбольный матч. Это не „наши” против „их”. Это всегда сначала, потом и в конце смерть.

Елена Стяжкина

Kwestia politycznej, kulturowej i mentalnej odmienności Donbasu dawała o sobie „boląco” znać na Ukrainie od samego początku

${ }^{1}$ К. Яковленко, „Тревожная штука эта наша современность. Но жить в ней можно и даже нужно", http://www.korydor.in.ua/ua/opinions/vladimirrafeenko-trevozhnaya-shtuka-e-ta-nasha-sovremennost-no-zhit-v-nej-mozhno-i-dazhe-nuzhno.html (30.01.2017).

2 Е. Стяжкина, „Донбасс не вернется в Украину, потому что Донбасса не существует", http://reinvent.platfor.ma/elena-styazhkina/ (7.04.2017). 
jej niezależnej od ZSRR ścieżki rozwoju, czyli od $1991 \mathrm{roku}^{3}$. Co prawda siła natężenia owego „dawania o sobie znać” pozostawała różna: od znajdywania się $\mathrm{w}$ centrum do pozostawania na marginesie społecznej uwagi, lecz z całą pewnością - spoglądając obecnie na minione ćwierćwiecze ukraińskiej niezależności - nie będzie przesadą stwierdzenie, że stanowiła ona kluczową składową tworzenia posowieckiej państwowości ukraińskiej. Widać to szczególnie dobrze, niestety, zwłaszcza w obliczu toczącej się na wschodzie Ukrainy wojny, która w tragiczny sposób uwypukliła fatalne pomyłki, zaniechania, przemilczenia etc. zarówno władz na szczeblu centralnym, jak i regionalnym, których konsekwencją okazał się dramat humanitarny dwóch wschodnio-południowych regionów Ukrainy: Łuhańszczyzny i Doniecczyzny, eufemistycznie nazwanych w początkowym okresie wojny rosyjsko-ukraińskiej jako ATO: strefa antyterrorystycznej operacji; regionów, dla których nadziei na pozytywne zakończenie wojny wciąż nie widać.

Nie od dziś wiadomo, że swoistość Donbasu jest produktem jego złożonej i nierzadko sprzecznej historii oraz konsekwencją trwałych socjalno-ekonomicznych, społeczno-politycznych i etnokulturowych procesów o charakterze kolonizacyjnym (carskiej Rosji) i totalitarnym (sowieckiej Rosji); procesów, które były absolutnie przeciwstawne do narodotwórczych dążeń Ukrainy.

Przypomnę tylko, że Donbas swoją nazwę zawdzięcza Jewgrafowi Kowalewskiemu - charkowskiemu inżynierowi górnictwa, który w latach 20. XIX wieku badał tamte tereny pod kątem występowania złóż węgla i który skonstruował pierwszą mapę pokładów tego surowca na terenie dzisiejszych obwodów donieckiego i łuhańskiego, jakie na wzmiankowanej mapie otrzymały nazwę Donieckiego Basenu - w skrócie Donbas. Z kolei w latach 1919-1920 bolszewicy stworzyli doniecką gubernię, scalającą ziemie Wojska Dońskie-

\footnotetext{
${ }^{3}$ Prezentowany tekst stanowi fragment monografii Wyjść z milczenia. Formy dekolonialnego dyskursu w ukrainskich narracjach literackich XXI wieku, która ukaże się w 2018 roku nakładem Wydawnictwa Kolegium Europy Wschodniej we Wrocławiu. Podstawę do jego napisania stanowił referat Pamięć - zapomnienie - przemilczenie $w$ literaturze ukraińskiej końca XX - poczatku XXI wieku (dyskurs donbaski), wygłoszony przeze mnie w IFS UAM na międzynarodowej konferencji naukowej Krajobraz po transformacji, Poznań 21-22.11.2016 r.
} 
go, katerynosławską i charkowską gubernię, której sercem, swojego rodzaju motorem napędowym, władza bolszewicka uczyniła rejony wydobycia węgla ${ }^{4}$. Zapleczem dla rozwoju owego regionu - zapleczem żywieniowym i roboczym - miały być natomiast tamtejsze obszary wiejskie i zamieszkująca je ludność. W latach stalinowskiej industrializacji władza pilnie pracowała nad stworzeniem wizerunku Donbasu jako „panradzieckiej kotłowni”, kraju przemysłowego, którego „sól ziemi” stanowi „klasa-hegemon”- robotnicy, a ich elitę - górnicy. Katalizatorem wzmocnienia owego wizerunku okazała się doba drugiej wojny światowej oraz czasy powojenne, które oprócz zintensyfikowanej polityki industrializacyjnej, związanej z działaniami wojennymi, a potem $z$ odbudową kraju po wojennych zniszczeniach, cechowała także zamierzona polityka oraz ideologia przesiedleńcza ${ }^{5}$ władzy sowieckiej, której przyświecała na

${ }^{4}$ Szukając korzeni mitu donbaskiego separatyzmu, warto mieć także na uwadze - częstokroć zapominaną w danym aspekcie, a cieszącą się zadziwiającą popularnością na terytorium obecnych DRL i ŁRL - historyczną efemerydę w postaci Donbasko-Krzyworoskiej Republiki Radzieckiej. Zob. В. Солдатенко, Донецько-Криворізька Радянська Республіка (ДКРР), w: В. Смолій i in. (red.), Енциклопедія історії України, t. 2, В-во „Наукова думка”, Київ 2004, s. 688; tegoż, Донецько-Криворізька республіка. Історія сепаратистського міфуy, „Історична правда” (11.02.2011), http://www.istpravda.com.ua/ articles/2011/02/11/23624/ (7.04.2017); А. Салтан, Зачем ЛУГАНДОНии нужна „реанимация” истории Донеико-Криворожской республики?, http:// sled.net.ua/lugandoniya/dkr/2015/25/04 (7.04.2017). Dziękuję Natalii Kuzin i Natalii Teres za zwrócenie mi uwagi na ów fakt - A.M.

${ }^{5}$ Wojna rosyjsko-ukraińska sprowokowała wśród polityków, historyków oraz dziennikarzy rosnące zainteresowanie procesami migracyjnymi, zachodzącymi w Donbasie. W związku z tym telewizja BBC wyemitowała cykl programów, poświęconych owej problematyce. Zob. np. C. Дорош, „Донбаський вузол”: як заселяли шахтарський край (4.07.2016), http://www.bbc.com/ukrainian/ society/2016/07/160510_donbass_migration_ussr_sd (5.04.2017); tejże, „Донбаський вузол": менталітет і сепаратизм (7.07.2016), http://www. bbc.com/ukrainian/politics/2016/07/160606_donbass_mentality_identity_sd (5.04.2017); tejże, „Донбаський вузол”: цүна повернення Донбасу (12.07.2016), http://www.bbc.com/ukrainian/politics/2016/07/160607_donbass_way_ back_sd (5.04.2017). Z wcześniejszych opracowań naukowych warto zwrócić szczególną uwagę na badania dwóch historyków: Jurija Nikołajca oraz Dmytra Tytarenki: Ю. Ніколаєць, Етнокультурний простір та міжетнічна інтеграція в Донбасі у другій половині ХХ сm., Украйна-Європа-Світ. 
wskroś totalitarna idea „wykorzenienia”/„oderwania od gruntu”. I nie chodziło tu tylko o wykorzenienie fizyczne, lecz także o jego znacznie bardziej nośną w negatywne dla wspólnoty skutki: wykorzenienie symboliczne - psychologiczne, mentalne, tożsamościowe ${ }^{6}$. Dzięki praktykom wykorzenienia reżim sowiecki niszczył tkankę narodu/wspólnoty, jego/jej wewnętrzną siłę, która spajałaby naród/wspólnotę, utrzymywałaby przy życiu jego/jej kulturę, podsycając jednocześnie narodowy/wspólnotowy rozwój. Polityka przesiedleńcza realizowana była nie tylko poprzez masowe deportacje ludności donbaskiej, ale także na drodze zasiedlania owego regionu poprzez odpowiednio ukierunkowaną wszechradziecką politykę zatrudnieniową. Poza tym Donbas przez cały okres ra-

Міжнародний збірник наукових праць, t. 10, Тернопіль 2012, s. 388-390; tegoż, Демографічні процеси на Донбасі у другій половині 50-x-на початку 80- $x$ pp. XX cm., „Наукові записки Вінницького державного педагогічного університету ім. Михайла Коцюбинського” 2012, t. XX, s. 144-151; tegoż, Міжетнічна взаємодія в Донбасі у другій половині XX cm., „Наукові записки Ін-ту політичних і етнонаціональних досліджень ім. І.Ф.Кураса НАН України” 2012, nr 5, s. 4-26; Д. Титаренко, Успішний Донбас без Украӥни неможливий. Так само як успішна Україна неможлива без Донбасу, http://www.historians.in.ua/index.php/en/intervyu/1900-dmytro-tytarenkouspishnyi-donbas-bez-ukrainy-nemozhlyvyi-tak-samo-iak-uspishna-ukrainanemozhlyva-bez-donbasu (5.04.2017).

${ }^{6}$ Sytuacja wykorzenienia, pozbawienia jednostki ludzkiej prawa do własnego terytorium, do własnego miejsca na świecie, to nie tylko kwestia wolności i sprawiedliwości; to znacznie więcej: to skrajnie rozpaczliwa sytuacja „pozbawienia prawa do posiadania prawa” i „przynależności do pewnego rodzaju zorganizowanej społeczności”. Totalitaryzmy spowodowały, że utrata domu i statusu politycznego stała się równoznaczna $\mathrm{z}$ wygnaniem $\mathrm{z}$ ludzkości. „Toteż nie utrata określonych praw - pisze Arendt - ale utrata społeczności, gotowej i będącej w stanie gwarantować jakiekolwiek prawa, była nieszczęściem [...]. Okazuje się, że człowiek może utracić wszystkie tzw. prawa człowieka, nie tracąc swojej podstawowej cechy, godności ludzkiej. Dopiero utrata państwa jako zbiorowości politycznej wyłącza go z człowieczeństwa”. I dalej: „Ci, którzy przeżyli obozy zagłady, więźniowie obozów koncentracyjnych i obozów dla internowanych, mogli [...] zauważyć, że abstrakcyjna nagość bycia tylko istotą ludzką stanowiła dla nich największe zagrożenie. [...] Tylko ich przeszłość z jej „wieczystym dziedziczeniem” potwierdza, że wciąż należą do cywilizowanego świata”. H. Arendt, Korzenie totalitaryzmu, przeł. D. Grinberg, M. Szawiel, t. 1, Wydawnictwa AkademickieiProfesjonalne, Warszawa 2008, s. 412-413,416-417. 
dziecki sam w sobie przyciągał masowy napływ „świeżego” czynnika ludzkiego, stanowiąc wschodni wariant Klondike. W planie fizycznym Donbas oferował możliwość rozpoczęcia nowego życia, w planie symbolicznym zaś - odsyłał do historycznych korzeni owego regionu jako pogranicza: bramy, przez którą niegdyś Kozacy podążali, by zawładnąć Dzikimi Polami. Dlatego też Donbas obfitował nie tylko w przestępców, uciekających przed wymiarem sprawiedliwości, ale także, zwłaszcza po drugiej wojnie światowej, w ludzi „odmiennie myślących” niż nakazywała władza sowiecka, w tzw. szkodliwy czynnik burżuazyjno-kapitalistyczny; to przeważnie z niego formował się inżyniersko-techniczny trzon donbaskiego przemysłu, na który władza „wspaniałomyślnie” przymykała tutaj oko, ponieważ był on jej potrzebny do rozwoju przemysłu? Dlatego też na tak uformowanym pod względem „ludzkim” obszarze reżim sowiecki musiał zastosować wyjątkową politykę „,zujności ideologicznej”, która pozwalałaby zachować mu „sprawny rząd dusz" nad mieszkańcami Donbasu. Stąd władza wykorzystała wobec mieszkańców owego regionu wyjątkowo silne ideologiczne mechanizmy sowietyzacyjne, przy jednoczesnym wykreowaniu społeczno-ekonomicznego i socjo-kulturowego mitu o unikalności Donbasu zarówno w samym Związku Radzieckim, jak i w całej Europie. Był to mit stworzony z myślą o autoidentyfikowaniu się miejscowej wspólnoty, dla którego fundamentalne kryterium stanowił region, nie zaś jakaś większa czy to terytorialna, czy to etniczna, czy też polityczna wspólnota. Tego typu działania naturalnie nie sprzyjały budowaniu jednolitej tożsamości narodowej, wytworzyły natomiast specyficzną hybrydową tożsamość regionalną - ni to rosyjską, ni to ukraińską, a właśnie donbaską, która po rozpadzie

${ }^{7}$ Obszernie pisze o tym japoński historyk, sowietolog Hiroaki Kuromiya w monografii Freedom and Terror in the Donbas: A Ukrainian-Russian Borderland, 1870s-1990s, Cambridge University Press, Cambridge 1998.

${ }^{8}$ Zob. A. Swain (red.), Re-constructing the Post-Soviet Industrial Region: The Donbas in Transition, Routledge, London-New York 2007 (zwłaszcza: A. Swain, V. Mykhnenko, The Ukrainian Donbas in „transition”, s. 7-46; K. Zimmer, Trapped in Past Glory. Self-identification and self-symbolisation in the Donbas, s. 97-121); T. Zhurenko, Borderlands into Bordered Lands: Geopolitics of Identity in Post-Soviet Ukraine, Ibidem Verlag, Stuttgart 2014. 
ZSRR i w realiach budowy ukraińskiej państwowości straciła swą rację bytu. Zrodziło się więc pytanie: jak odnaleźć się mieszkańcom Donbasu, ale i też pozostałym obywatelom Ukrainy, z rzeczonym uprzywilejowanym donbaskim regionalizmem (i z właściwym mu specyficznym donbaskim patriotyzmem ${ }^{9}$ ) w sytuacji państwotwórczej osadzonej na kryterium narodowym tożsamym $\mathrm{z}$ etnicznym? Pytanie owo było przez kolejne ekipy rządzące w dyskursie publicznym skrzętnie i zmyślnie pomijane, co miast prowadzić do zjednoczenia, eskalowało rozłam ukraińskiego społeczeństwa, które dodatkowo skutecznie było (po)dzielone przez konfliktogenną w swej istocie politykę pamięci (zarówno za czasów sowieckich, jak i już po upadku ZSRR), jaka dla środkowo-wschodnich obszarów Ukrainy z przyczyn historyczno-politycznych ufundowana była na sowieckim micie wielkiej wojny ojczyźnianej, dla zachodnich i południowo-zachodnich terytoriów ukraińskich zaś - na nacjonalistycznym micie OUN i UPA ${ }^{10}$.

Jednak dyskusje o donbaskiej specyfice po Euromajdanie przestały nosić znamiona „niewinnych i bezpłodnych” intelektualnych deliberacji, w których - zwłaszcza w latach 2000 - sprzeczano się o to, czy można mówić o dwóch ukraińskich tożsamościotwórczych paradygmatach: wschodnim i zachodnim, czy też o co najmniej trzech, jeśli nie „dwudziestu dwóch” (nawiązuję tu do głośnej dyskusji kijowskiego politologa Mykoły Riabczuka i lwowskiego historyka Jarosława Hrycaka) ${ }^{11}$. Dzisiaj echa tamtych dyskusji zo-

9 Zob. С. Пахоменко, Ідентичність у конфлікті на Донбасі, http://www. historians.in.ua/index.php/en/dyskusiya/1556-serhii-pakhomenko-identychnist-u-konflikti-na-donbasi (17.03.2017).

10 Zob. np. М. Рябчук, Культура памяти и политика забвения, „Отечественные записки” 2007, nr 1, http://www.strana-oz.ru/2007/1/kultura-pamyatii-politika-zabveniya (12.01.2017); Я. Грицак, Українська ідентичність, „Критика” 2016, nr 3-4 (marzec), s. 18-21.

11 Zob. m.in. Я. Грицак, Одна, дві, двадиять дві..., http://zaxid.net/news/ showNews.do?odna_dvi_dvadtsyat_dvi\&objectId=1061835 (1.04.2017); tegoż, Двадияать дві України, „Критика” 2002, nr 4; tegoż, Украӥна між Сходом і Заходом: стара історія на новий лад, w: tegoż, Страсті за націоналізмом. Старі історії на новий лад, Критика, Київ 2011, s. 279-299; М. Рябчук, Дві України, http://www.ji-magazine.lviv.ua/dyskusija/arhiv/ryabchuk.htm 
stały zagłuszone przez strzelaninę toczącej się na Donbasie wojny hybrydowej i przysłonięte trupami poległych tam żołnierzy oraz ginącej - w wymiarze materialnym i niematerialnym, cielesnym i duchowym - ludności cywilnej. Sytuacja impasowości donbaskiej tragedii jest tym większa, że region ten nieustannie poddawany jest - oprócz jawnych i ukrytych działań militarnych - także niesłabnącemu atakowi propagandy rosyjskich mediów, „troskliwie dbających” w duchu neoimperialnej ideologii „Ruskiego świata”, by poziom dezorientacji miejscowej ludności co najmniej nie zmalał ${ }^{12}$.

(1.04.2017); tegoż, „Колоніальний статус Украйни був очевидний для мене вже у стариих класах", http://www.ji-magazine.lviv.ua/anons2013/ Ryabchuk_Kolonialnyj_status_Ukrainy.htm (1.04.2017); tegoż, Дві Украӥни: кінецьь амбівалентности?, https://krytyka.com/ua/articles/dvi-ukrayinykinets-ambivalentnosty (1.04.2017); Т. Возняк, Геополітичні контексти війни в Україні, http://www.ji.lviv.ua/ji-library/Vozniak/Geopolitychni\%20 konteksty\%20vijny\%20v\%20ukrajini/geopolityka_zmist.htm (1. 02.2017).

${ }^{12}$ Symulakryczny obraz rzeczywistości noworosyjskiej kreuje stacja RT (Russia Today, https://russian.rt.com/tag/novorossiya), wspierana przez liczne portale internetowe. Zob. Np. Новороссия. Новостной аналитический портал (http://novorossia.su/ru); Новости Новороссии (http://novorus.info); Русская весна (http://rusvesna.su/tags/novorossiya). Kluczowe zasługi w tej materii mają również publicyści, pisarze i eksperci związani z Klubem Izborskim. Zob. np. takie publikacje jak: Спасти Украину! Меморандум экспертов Изборского клуба (13.02.2014), https://izborsk-club.ru/2602; С. Глазьев, Украина: между Западом и Россией. Предварительные итоги украинского переворота (25.04.2014), https://izborsk-club.ru/3069 (1.04.2017); А. Проханов, Убийство городов, Эксмо, Москва 2015; В. Даренский, О современной военной литературе Донбасса, „Изборский клуб” 2016, nr 5, http://old.izborskclub.ru/content/articles/10164/; forum w Ługańsku nt. Что такое Русская цивилизация (8.06.2016), https://izborsk-club.ru/9393; 3. Прилепин, Украина бесстыдно лжет (1.02.2017), https://izborsk-club.ru/12270; okrągły stół nt. Возможна ти дружба России с Украиной? (23.03.2017), https://izborskclub.ru/12840; В. Коровин, Имперский разговор. Империя, геополитика, идеология, традиция, Книжный мир, Москва 2016; С. Глазьев, Украинская катастроба: от американской агрессии к мировой войне?, Книжный мир, Москва 2016; А. Проханов, Новороссия, кровью умытая. Передовицы, Книговек, Москва 2016; tegoż, Русский камень, Терра, Москва 2017, https:// izborsk-club.ru/12924 [odczyt tekstów bez podanej przy nich konkretnej daty pochodzi z dnia 5 kwietnia 2017] i in. Zob. także: Ю. Ніколаєць, Роль мас-медіа дискурсу у бормуванні регіональної ідентичності жителів Донбасу наприкінці XX - на початку XXI cm., „Наукові записки Ін-ту 
Kultura, jak wiadomo, w takich chwilach okazuje się wyjątkowo czułym barometrem sytuacyjnym. Nie jest inaczej i z obecną kulturą ukraińską, która - jak to w historii Ukrainy po wielokroć już bywało (nie tylko w dobie nowożytnej) - w obliczu braku (odpowiednich) ram polityczno-państwowych przejmuje misję kreatora przestrzeni do dyskusji społeczno-narodowej. To właśnie w przestrzeni kultury oraz nauki - $\mathrm{w}$ przeciwieństwie do realiów politycznych - został zapoczątkowany oddolnie kształtowany dekolonialno-detotalitarny zwrot w jakości treści dyskursu wokół Donbasu.

Jednym z pierwszych takowych działań kulturowych była inicjatywa Narodowego Forum Kultury „Donkult - Artystyczne Zagłębia” („Донкульт - Мистецькі Надра”), które po raz pierwszy odbyło się w Kijowie na przełomie października i listopada 2014 roku, po raz drugi natomiast - we Lwowie w czerwcu 2015 roku. „Donkult", zarówno ten kijowski, jak i lwowski, obejmował kilkadziesiąt różnych wydarzeń, w tym wystawy artystyczne, projekcje filmów, koncerty, spotkania z pisarzami, a także wykłady i debaty. Celem obu forów, jak anonsowali sami organizatorzy, było przedstawienie osiągnięć kulturalno-naukowych Donbasu. Pierwsza edycja „Donkultu" wzbudzała mieszane uczucia. Z jednej strony odnosiło się wrażenie, jakby sami przedstawiciele prezentowanej donbaskiej kultury i nauki chcieli powiedzieć: „Zobaczcie, nie jesteśmy tylko lumpenproletariatem, też mamy swoje środowiska intelektualne". $\mathrm{Z}$ drugiej strony natomiast jakby pozostała część Ukrainy chciała poprzez tę wystawę ukłonić się i powiedzieć: „Pamiętamy o was, kochamy was". Być może był to poniekąd symboliczny gest przeprosin za wieloletni brak dobrej woli, by chcieć pamiętać i zrozumieć złożoną specyfikę tego regionu ${ }^{13}$, który niewątpliwie ma histo-

політичних і етнонаціональних досліджень ім. І.Ф.Кураса НАН України” 2013, nr 5, s. 84-108; P. Pieniążek, Pozdrowienia z Noworosji, Wydawnictwo Krytyki Politycznej, Warszawa 2015. Istotę owej symulakrycznej rzeczywistości wojennego Donbasu znakomicie uchwycił Ołech Łoznica w nagrodzonym za najlepszą reżyserię na tegorocznym Cannes Un Certain Regard filmie Donbas (premiera 9.05.2018 r.).

13 Zob. T.A. Olszański, Co ujawniła Rewolucja Godności, „Kultura i Społeczeństwo" 2015, nr 2, s. 215-226. Zob. też ciekawy wywiad Donbas było stać tylko na oszustów i złodziei. Ołeksij Czupa w rozmowie z Pawłem Pieniążkiem, 
rycznie ważne znaczenie dla całej kultury ukraińskiej ${ }^{14}$. I niestety, trzeba było wojny, by mogło dojść do zainicjowania symbolicznego pojednania (choć de facto w miarę rozwoju wydarzeń wojennych w horyzoncie społeczno-politycznym wydaje się ono coraz mniej realne), które poprzez miejsce edycji drugiego forum - Lwowa, reprezentującego Zachodnią Ukrainę - nabrało jeszcze większego znaczenia (nota bene, w dniach 4-18 września 2016 roku w Charkowie odbyła się trzecia odsłona owej inicjatywy, która w tzw. międzyczasie przybrała szerszą skalę i nową nazwę: Kulturowe Forum PogranKult; tym razem była to GalicjaKult) ${ }^{15}$.

Inną ciekawą inicjatywą tego typu był odbywający się w marcu 2016 roku na przyfrontowych terenach Łuhańszczyzny literacko-muzyczny festiwal „Droga na Wschód”, w którym wzięły udział — w wyniku kooperacji twórczego stowarzyszenia „Ostatnia Barykada”, artystycznej agencji „Terytorium A” oraz kijowskiego wydawnictwa „Smołoskyp" - czołowe ukraińskie zespoły rockowe oraz pisarze, wywodzący się z pierwszego i drugiego pokolenia tranzycyjnego (w tym m.in. Kozak System, Żadan i psy w Kosmosie, Urbanistan, Izobarra TOR, Dmytro Łazutkin, Artem Połeżaka), którzy oprócz „kaganka kultury ukraińskiej” przywieźli ze sobą pomoc humanitarną, zorganizowaną przez wolontariuszy z całej Ukrainy. Artyści na towarzyszących festiwalowi konferencjach prasowych tłumaczyli, że swój udział w tym przedsięwzięciu traktują jako jeden z wielu kroków na drodze do umocnienia współpracy ze współobywatelami Wschodu Ukrainy, jako próbę nawiązania komunikacji międzyregionalnej oraz próbę pokonania niedowierzania wobec tzw. donbaskich.

Nazwa festiwalu to metafora, ale też $\mathrm{w}$ istocie swej ta realna trasa $\mathrm{z}$ Charkowa do Starobielska bardzo dobrze odzwierciedla naszą wspólną drogę: nas na Wschód i Wschodu do nas. Trasa ta została zniszczona nie tylko przez wojsko-

http://www.krytykapolityczna.pl/artykuly/ukraina/20141218/czupa-donbasbylostac-tylko-na-oszustow-i-zlodziei (20.11.2016).

${ }^{14}$ Zob. А. Виттковски, Пятилетка без плана: Украина: 1991-1996: Формирование национального государства, экономика, элиты, przeł. Н. Комарова, Сфера, Киев 1998, s. 23-57; Н. Kuromiya, Freedom and Terror in the Donbas...

${ }^{15}$ Zob. https://www.dofa.fund/zagalna (20.01.2017). 
wą technikę, ale także przez brak skoordynowanych działań wojskowego dowództwa. Tak czy inaczej, kiedyś przyjdzie nam wyremontować tę drogę i ustanowić nową komunikację ${ }^{16}$

— wyjaśniał Serhij Żadan. Z kolei Iwan Łenio, lider zespołu Kozak System, dodał, że hasło „Donbas to Ukraina” bez realnych działań zostanie tylko pustym zawołaniem. Artyści podkreślali także, że ich działaniom przyświeca również cel, by zaprzeczyć propagandowym twierdzeniom, że na Donbasiejestinna, specyficzna publiczność, którą nie interesuje kultura pozostałych regionów Ukrainy. „Wśród ludności cywilnej - jak mówił Dmytro Łazutkin, poeta i prezenter telewizyjny — jaką spotykamy na tyłach działań wojennych, jest wielu ludzi młodych o orientacji proukraińskiej, którzy chcą, żebyśmy do nich przyjeżdżali,żebyśmy z nimi rozmawiali; chcą też, by o nich usłyszano. A więc zainteresowanie proukraińskie jest i nie jest ono udawane"17.

W dobie około- i pomajdanowej - jak grzyby po deszczu zaczęły również pojawiać się publikacje naukowe (cząstkowe oraz monograficzne), podejmujące „palące pytania” donbaskiego dyskursu. Na zwrócenie uwagi zasługują w pierwszej kolejności przedsięwzięcia Instytutu Historii Ukrainy Narodowej Akademii Nauk Ukrainy w Kijowie, który zapoczątkował cykl popularno-naukowych wydań „Studia z regionalnej historii. Stepowa Ukraina”. Serii owej przyświecał zamysł zneutralizowania toksycznego wpływu rosyjskiego neoimperializmu, który pretenduje do zajmowania nie tylko terytorium Ukrainy, ale i ukraińskiej przestrzeni medialnej, co więcej: ukraińskiej historii oraz pamięci kolektywnej. I to właśnie z inicjatywy badaczy tegoż Instytutu (Stanisław Kulczycki i Łarysa Jakubowa) w październiku 2016 roku ujrzała światło dzienne fundamentalna monografia przedstawiająca kulturowo-historyczny rozwój Donbasu (Trzysta lat samotności: Donbas $w$ poszukiwaniu wartości i ojczyzny $\left.{ }^{18}\right)$. Publikacja ta, oprócz

\footnotetext{
16 https://www.ukrinform.ua/rubric-culture/1982424-festival-doroga-na-shidprolaze-cerez-svatove-ta-starobilsk-zadan.html (5.02.2017).

17 Tamże.

${ }^{18}$ С. Кульчицький, Л. Якубова, Триста років самотності: Донбас у пошуках смислів і батьківщзин, ТОВ Видавництво Кліо, Київ 2016.
} 
gruntownego rozpracowania problemu, zawiera także bogatą wielojęzyczną bibliografię, która może stanowić kapitalny punkt wyjścia do dalszych studiów w tym zakresie ${ }^{19}$.

Z kolei rok wcześniej (w 2015 roku) na ukraińskim rynku wydawniczym pojawił się także pod egidą kijowskiego Instytutu Historii Ukrainy NAN zbiorek filozoficzno-kulturologicznych esejów jednego z najznakomitszych i jednocześnie jednego z najbardziej opiniotwórczych ukraińskich autorytetów intelektualnych, Iwana Dziuby, niegdysiejszego duchowego przywódcy odrodzeńczego ruchu społeczno-kulturowego pokolenia tzw. sześćdziesiątników. Zbiorek ów nosi symptomatyczny tytuł Doniecka rana Ukrainy. Na jego treść składają się trzy obszerne teksty, które Dziuba - sam rodem z Donbasu - napisał w ważnych dla owego regionu momentach historycznych $\mathrm{z}$ myślą o konstruktywnej dekonstrukcji/ demitologizacji donbaskiego mitu. Z 2001 roku pochodzi tekst Doniecczyzna - kraina ukraińskiego słowa. Dziuba opublikował go po serii prowokacji mających miejsce w Kijowie, które straszyły miejscową ludność nadejściem oligarchii „Donieckich” wraz z ich kryminalnym systemem sprawowania władzy. Kolejny tekst, Doniecka składowa ukraińskiej kultury, powstał w związku z Międzynarodowym Kongresem Ukrainistów, odbywającym się w Doniecku w 2005 roku, tj. niespełna w rok po pomarańczowej rewolucji, jaka w dramatyczny sposób skonfrontowała Wschód i Zachód Ukrainy. I wreszcie ostatni esej - Tragedia Doniecczyzny - pochodzi z 2014 roku i dotyczy aktualnych wydarzeń wojennych na Donbasie. Publikacji tomiku, jak sam autor oznajmił we Wstępie, przyświecał zamysł, by w wymiarze ekonomicznym, geopolitycznym, historyczno-kulturowym, religijnym oraz mentalnym spróbować wyświetlić i zrozumieć przyczyny, które umożliwiły w 2014 roku rosyjską agresję i wciąż trwającą rosyjską okupację Donbasu, jak i masową iluzję części mieszkańców tegoż regionu, którzy pod szyldem Donieckiej i Łuhańskiej Republik Ludowych znaleźli się w neoimperialnym potrzasku „toksycznych objęć” putinizmu.

${ }^{19}$ Polskiemu czytelnikowi specyfika Donbasu została przybliżona w monografii M. Studennej-Skrukwy Ukraiński Donbas. Oblicza tożsamości regionalnej, Wydawnictwo Nauka i Innowacje, Poznań 2014. 
Wspomniane eseje w kontekście omawianego przeze mnie tematu są interesujące choćby dlatego, że „przypominają” one Ukraińcom, iż to właśnie z Donbasem są związane tak znaczące postacie ich rodzimej kultury, jak: w latach 20. XX wieku Mykoła Skrypnyk, autor ukraińskiej wersji polityki ukrainizacyjnej; jeden z czołowych poetów dwudziestowiecznej literatury ukraińskiej Wołodymyr Sosiura, a także Kost' Herasymenko, Hryhorij Bahliuk, Wasyl Hajwarons'kyj, tworzący ugrupowanie „Забой”, które w drugim dziesięcioleciu minionego wieku kreatywnie i efektywnie włączyło się w akcję ukrainizacji Donbasu (ceną było własne życie). Z tamtej części Ukrainy pochodzą także kluczowe postacie tzw. sześćdziesiątników, tj. wspomniany Iwan Dziuba, Iwan Switłycznyj, Wasyl Hołoborodz'ko oraz Wasyl Stus, uważany za kongenialnego poetę ukraińskiego drugiej połowy XX wieku, który niewątpliwie - jeśli dane by mu było dożyć czasów niezależnej Ukrainy (poeta $\mathrm{w}$ wieku 47 lat został zamordowany w łagrze w 1985 roku, a więc już w dobie gorbaczowowskiej), byłby typowany do literackiej nagrody Nobla. Warto pamiętać także i o emigracyjnych twórcach urodzonych na Donbasie takich jak poeta, publicysta i krytyk literacki Łeonid Łyman (USA) czy prozaik i dziennikarz Witalij Bender (Wielka Brytania) oraz poetka i malarka Emma Andijewska (związana niegdyś z „Grupą Nowojorską", a obecnie mieszkająca w Niemczech).

Spośród aktualnie tworzących na Ukrainie pisarzy o donbaskich korzeniach nie można pominąć też Iren Rozdobudz'ko, autorki popularnej prozy kobiecej, która od dłuższego czasu bije rekordy czytelniczej popularności, jak i pochodzącego z Makijiwki Ołeksija Czupy, autora głośnych aktualnie powieści, przełożonych również na język polski - Bezdomni Donbasu, Dziesięć słów o ojczyźnie oraz Bajki $z$ mojego schronu (wszystkie książki wydano w 2014 roku), Akwarium (2016). Jednakże z całą pewnością rola „lidera” przypada dwójce pisarzy, czyli ukraińskojęzycznemu Serhijowi Żadanowi oraz rosyjsko-ukraińskojęzycznemu Władimirowi Rafiejence.

Obaj są swego rodzaju - acz, co istotne, niebezrefleksyjnymi (sic!) - apologetami narracji donbaskiej w literaturze ukraińskiej. Na pytanie, dlaczego kochają Donbas, które postawiłam w jednym 
z wywiadów przeprowadzonych z oboma pisarzami pod koniec 2014 roku, odpowiedzieli tak ${ }^{20}$ :

Władimir Rafiejenko: Geopoetyka Donbasu to temat na osobną rozmowę. Jednak teraz to zbyt trudny i zbyt bolesny dla mnie temat. Mogę jedynie powiedzieć, że architektonika przestrzeni, w której się urodziłem, w której dorastałem, z którą związałem swoje dotychczasowe dorosłe życie, jest nadzwyczaj skomplikowana. To ziemia uwznioślająco nasycona metaforami, ciężką pracą, ale i miodem. To step, rzeki, to ziejące pustką wielokilometrowe korytarze wydrążone pod ziemią, a nad nimi piętrzące się hałdy, ponad którymi wiosną unosi się zapach kwitnących wiśni, moreli, jabłoni; to gorące oślepiające słońce, zapach rozgrzanej ziemi; to język ukraiński w wariancie południoworosyjskim; to stoły biesiadne z rozbrzmiewającymi pieśniami w trzech-czterech językach; to wreszcie brak realnej kulturowej perspektywy - wszystko rozgrywa się w płaszczyźnie mitologicznej, nie wyłączając najdrobniejszych spraw codziennych, ekonomicznych, politycznych; to również poczucie wyłączenia z kontekstu rosyjskiego, ale $\mathrm{z}$ drugiej strony i uczucie nieprzystawania do kontekstu ukraińskiego; to jednocześnie uczucie osierocenia i wolności. A nad tym wszystkim Bóg. Tylko wrosnąwszy w codzienność Donbasu, można odczuć jego tragiczne piękno.

Serhij Żadan: Są pewne rzeczy, które człowiek kocha nieświadomie, po prostu dlatego, że nie może ich nie kochać. Kocha, ponieważ to jego ojczyzna. To są rzeczy, które są człowiekowi po prostu dane. Dla mnie to jest właśnie krajobraz, który sobie uświadomiłem jako pierwszy. Pamiętam kilka momentów związanych z krajobrazem Donbasu. Kiedyś pojechaliśmy na Donbas z Lubką Dereszem i Jurijem Andruchowyczem. Jeśli się nie mylę, to było w 2007 albo 2008 roku. Pamiętam zachwyt Jurija, gdy ten po raz pierwszy zobaczył hałdy; Andruchowycz nawet to później opisał. To jest ten rodzaj zachwytu, gdy człowiek widzi coś po raz pierwszy. Rzeczywiście takiego landszaftu nie da się zobaczyć nigdzie indziej. Pojechaliśmy też na Donbas - do Ługańska, Ałczewska, Perewalska i Doniecka — pod koniec kwietnia 2014 roku. Wtedy można było jeszcze tam pojechać i zrealizować projekt. To było bardzo dziwne doświadczenie: separatyści już działali na tych terenach, ale jeszcze można było tam się dostać, ich punkty kontrolne istniały raczej nominalnie. Wówczas panowała bardzo ciepła donbaska wiosna $\mathrm{z}$ masą niesamowitych zapachów. Jechaliśmy w środku nocy z Ługańska do Ałczewska, a za kierownicą siedziała moja bliska przyjaciółka, która zachwycona mówiła, że okolica jest piękna, że przypomina jej Gruzję i góry. Odpowiedziałem jej, że to nie są góry, lecz hałdy. Rzeczywiście możemy tam zobaczyć niesamowity krajobraz stworzony rękoma ludzi. Pewna znana piosenka rozsławiła obraz donieckiego stepu, ale to nie

${ }^{20}$ Donbas - moja miłość. Serhij Żadan, Władimir Rafiejenko i Jurij Wołodarski w rozmowie z Agnieszką Matusiak i Anną Ursulenko opowiadają, za co i dlaczego kochają wschód, przeł. z ukr. A. Ursulenko, „Miscellanea Posttotalitariana Wratislaviensia" 2016, nr 4, s. 145-153. 
jest metafora, tam naprawdę jest step. To jest płaski teren, a jeżeli są wzniesienia, to stamtąd widać na dwadzieścia-trzydzieści kilometrów w dal, na przykład w mieście Izium, na Sawur-Mohyli albo w moim rodzinnym Starobielsku. Gdy człowiek stoi na takiej górze, to ma przed sobą widok na kilkadziesiąt kilometrów. To są rzeczy, które „nakładają się” na siatkówkę twojego oka i dlatego zaczynasz widzieć świat właśnie w taki, a nie inny sposób. To są rzeczy, które - niezależnie od tego, czy się tobie podobają lub nie - określają cię. Właśnie za to kocham Wschód.

Postać Serhija Żadana (ur. w 1974; rodem ze Starobielska, obwód Łuhański, a dziś mieszkający na stałe w Charkowie) jest w Polsce doskonale znana (choćby jako laureata nagrody Angelusa z 2015 roku, którą otrzymał za powieść Mezopotamia) - poeta, prozaik, performer, należący do tzw. pierwszej fali pokolenia postsowieckiej transformacji systemowej, tj. obecnych czterdziestolatków, a więc urodzonych w latach 70. XX wieku, w tzw. czasie zastoju breżniewowskiego, dorastających w latach 80, a więc w dobie agonii i krachu imperium radzieckiego, których wejście w dorosłość przypadło na burzliwe lata $90 .{ }^{21}$ Co istotne, to właśnie to pokolenie stanowiło w listopadzie 2013 roku zaczyn i trzon kijowskiego Euromajdanu; to ono podjęło się próby zmiany społecznego, ale także kulturowego, a w konsekwencji, być może, również narodowego oblicza współczesnej Ukrainy.

Serhij Żadan, jako aktywista społeczny, jest też jednym z pisarzy najbardziej zaangażowanych w działania na rzecz wypracowania konsensusu między mieszkańcami ATO a pozostałą częścią ukraińskiego społeczeństwa. Pisarz jest jednak świadom, że przy dzisiejszej eskalacji działań zbrojnych na Donbasie, rodzących i eskalację wzajemnego nie(po)zrozumienia się Ukraińców, co w konsekwencji - stopniowo zabijając szansę na pozytywny rozwój wypadków — powoduje wzrost $\mathrm{z}$ jednej strony ukropofobii, a $\mathrm{z}$ drugiej donbasofobii. W przekonaniu twórcy, owa agresja wobec Donbasu będzie

${ }^{21}$ Zob. M. Świetlicki, Kiedy chłopcy staja się mężczyznami? Męskość jako projekt w prozie Serhija Żadana, Wydawnictwo Uniwersytetu Wrocławskiego, Wrocław 2016; A. Matusiak, Pokolenie jako miejsce pamięci w prozie Serhija Żadana, w: A. Matusiak (red.), Posttotalitarny syndrom pokoleniowy w literaturach Europy Środkowej, Wschodniej i Południowo-Wschodniej konca XXI - początku XXI wieku $w$ świetle studiów postkolonialnych, Wydawnictwo Bonami, PoznańWrocław 2016, s. 225-252. 
jeszcze tylko bardziej przybierać na sile, zwłaszcza w obliczu coraz większej liczby ofiar po stronie ukraińskiej armii:

Jeśli założyć, że region ten pozostanie przynależny do Ukrainy, ale z własną administracją, oddzielnym systemem prawnym, własnym sztandarem i „ruskim światem", to trudno sobie wyobrazić, żeby Ukraina traktowała go jako pełnoprawny region. Konflikt [na Donbasie - A.M.] został sprowokowany w tak cyniczny i podły sposób, że jakikolwiek wariant jego rozwiązania pozostawi całą masę nierozwiązalnych problemów i nie mniejszą masę pytań bez odpowiedzi.

Kluczowe pytanie, które mu się dziś nasuwa, to jak należałoby/ jak można byłoby żyć „po konflikcie” z ludźmi, którzy uwierzyli w kłamstwa putinowskiej propagandy,

jak można byłoby jeździć tym samym transportem publicznym i siedzieć stolik w stolik obok ludzi, którzy byli po tamtej stronie frontu? [...] i czy setki tysięcy mieszkańców Donbasu, którzy stąd wyjechali, będą mogli/zechcą powrócić do swych domostw? [...] A jeśli wrócą, to jak odniosą się do nich Ci, którzy tam pozostali? Jeśli bowiem całe lato ktoś przesiedział pod obstrzałem, a ktoś inny wyjechał, to istnieje duże prawdopodobieństwo, że ten drugi zostanie potraktowany jak zdrajca, który porzucił swoje miasto ${ }^{22}$.

Serhij Żadan mimo wszystko nie ustaje jednak w podtrzymywaniu dialogu między okupowanymi terytoriami obwodu donieckiego i łuhańskiego a resztą Ukrainy. Wraz ze swoimi przyjaciółmi, także wolontariuszami, pisarz początkiem 2017 roku założył fundację charytatywną ${ }^{23} \mathrm{z}$ myślą o wsparciu działań medycznych, oświatowych i kulturowych dla strefy ATO. Żadan jest przekonany, że pomoc dla okupowanego Donbasu powinna mieć charakter zorganizowany oraz systematyczny i długofalowy, albowiem „rozwój sfery humanitarnej faktycznie określi to, jakie będzie ukraińskie społeczeństwo za 5-10 lat. Naszą intencją jest, by w przyszłości nikt nawet nie chciał pomyśleć, że Donbas można rozpatrywać w izola-

${ }^{22}$ С. Жадан, „У боротьбі з ворогами ми забуваємо про пошук союзників”, http://www.korydor.in.ua/ua/opinions/serhij-zhadan-vorohy-sojuznyky.html (20.11.2016).

23 Zob. Благодійний фонд Сергія Жадана, http://zhadancharity.org.ua/ (31.03.2017). 
cji od innych regionów Ukrainy. [...] Donbas potrzebuje dziś szczególnej uwagi i naszej wspólnej pracy dla wspólnej przyszłości"24.

Głosem, który obecnie należy uznać za najistotniejszy dla narracji donbaskiej, jest natomiast nie tyle pisarstwo Żadana, ile twórczość Władimira Rafiejenki (ur. w 1969 roku w Doniecku), który w 2014 roku z powodu działań wojennych zmuszony był opuścić rodzinny Donieck i zamieszkać w Kijowie; autora takich utworów prozatorskich, jak Krótka książka pożegnań (2000), Wakacje czarowników (2005), Czasowniki bezzwrotne (2009), Moskiewskie divertimento (2011), Demon Kartezjusza (2013), Po najdluższe czasy (2015/2016), a także tomików poetyckich Trzydniztygodnia (1998), Prywatny sektor (2002) i Przeprawa przez drogę (2003). Twórczość Rafiejenki stanowi najjaskrawsze odzwierciedlenie skomplikowanej sytuacji współczesnej ukraińskiej literatury rosyjskojęzycznejej. Dla rosyjskiego czytelnika jego pisarstwo może wydawać się lokalne, a nawet nieco egzotyczne - analogicznie, jak każda inna literatura napisana po rosyjsku, acz osadzona $\mathrm{w}$ realiach innego kraju, co więcej, innej mentalności. Jednakże wychowanek samego „serca górniczego Donbasu", piszący o mieście Z. (dla którego prototypem był współczesny Donieck ${ }^{26}$ ), nie wpasowuje się również w ukraiń-

\footnotetext{
${ }^{24}$ Wywiad opublikowano na portalu Depo.ua pod datą 21 stycznia 2017 r. Zob. także wywiad W. Rafiejenki z S. Żadanem (26 grudnia 2016): „Мир стабилен и прекрасен. Просто от этого рано или поздно умираешь", https://focus. ua/culture/362084/ (30.12.2016) oraz rozmowę Darii Tarasowej z S. Żadanem z 4 lipса 2016: „Багато хто забуває, що в Донецьку $і$ Луганську були свої Майдани", http://espreso.tv/article/2016/07/04/zhadan_bagato_khto_zabuvaye_scho_v_donecku_i_lugansku_buly_svoyi_maydany $(30.12 .2016)$.

${ }^{25}$ Problematykę tę poruszałam już wcześniej w artykule Międzyrzecze kultur. Rzecz o współczesnej rosyjskojęzycznej literaturze ukraińskiej, „Miscellanea Posttotalitariana Wratislaviensia” 2016, nr 4; A. Matusiak (red.), Pokolenie tożsamość - transformacja. Gardzienickie czytania teatroznawcze... i nie tylko, Wydawnictwo Uniwersytetu Wrocławskiego, Wrocław 2016, s. 158-166. Zob. też rozmowę Kateryny Jakowlenko z 27 stycznia 2017 roku z Władimirem Rafiejenką: http://www.korydor.in.ua/ua/opinions/vladimir-rafeenko-trevozhnaya-shtuka-e-ta-nasha-sovremennost-no-zhit-v-nej-mozhno-i-dazhe-nuzhno.html (30.01.2017).
}

${ }^{26}$ Zob. B. Рафеенко, Абрикосы Донбасса, „Русский журнал” 2014, http:// www.russ.ru/pole/Abrikosy-Donbassa (20.11.2015). 
skie ramy literackiego landszaftu ${ }^{27}$. Autor Demona Kartezjusza jest więc mieszkańcem transkulturowego międzyrzecza, egzystującym na skrzyżowaniu literatury ukraińskiej i rosyjskiej. Stąd geograficzna przynależność Rafiejenki nie ma odniesienia ani do Rosyjskiej Nagrody, którą ten jako jej zwycięzca otrzymał w 2013 roku właśnie za Demona Kartezjusza ${ }^{28}$ (z kolei w 2012 roku jego powieść Moskiewskie divertimento zajęła drugie miejsce w kategorii „Duża Proza” tej samej Rosyjskiej Nagrody), ani do krótkiej listy nagrody NOS z 2014 roku $^{29}$.

Ostatnia powieść Rafiejenki Po najdłuższe czasy opublikowana w 2017 roku niemalże jednocześnie i po rosyjsku, i po ukraińsku w przekładzie Mar'jany Kijanowskiej - filozoficznie wyrastająca z egzystencjalistycznej myśli Alberta Camusa oraz literackiej tradycji Martwych dusz Gogola, Mistrza i Małgorzaty Michaiła Bułhakowa czy prozy Wieniedikta Jerofiejewa - ustanawia w literaturze ukraińskiej nowy, dotąd niewybrzmiały, paradygmat pisania o wojnie: nie o (pan)radzieckiej wielkiej wojnie ojczyźnianej, kreślonej w ideologicznym duchu imperialnego zwycięstwa sowietyzmu nad

${ }^{27}$ Zob. wywiad Anny Biłej z Władimirem Rafiejenką, przeprowadzony w 2012 roku: Остается некоторая незримая граница внутри культуры одной страны..., http://archive.is/Ktj6O\#selection-173.19-173.86 (2.02.2017).

28 Warto podkreślić, że Demon Kartezjusza, stając w szranki Rosyjskiej Nagrody, znalazł się w jednym szeregu z takimi utworami jak Fabryka „Wolność" Ksenii Bukszy, Tellurium Władimira Sorokina czy Miłość do trzech zukerbrinów Wiktora Pielewina. W powieści Rafiejenki odnajdujemy i mroczne proroctwo, które się spełnia (konkurencja dla Sorokina?), i ciąg zaskakujących osobowościowych transformacji w wyniku aktu „migotania” (Pielewin ze swoimi „pociągami losu” włącza w podobny proces przeobrażeń wszystko i wszystkich). I oczywiście industria: zmitologizowane, jednak absolutnie rozpoznawalne, Donieckie Zakłady Metalurgiczne z Demona Kartezjusza, oraz na odwrót, całkowicie anonimowa, acz zobrazowana w duchu socrealistycznej powieści produkcyjnej fabryka zbrojeniowa $\mathrm{z}$ nośną w swej symbolice nazwą „Wolność” w powieści Bukszy. Zob. А. Грувер, Письмо из города Z. Опьт провинциального прочтения (Владимир Рафеенко. „Демон Декарта”), „Новый Мир” 2015, nr 1, http://magazines. russ.ru/novyi_mi/2015/1/16guv.html (20.11.2015).

${ }^{29}$ NOS - nagroda literacka Fundacji Michaiła Prochorowa, przyznawana co roku dla pisarzy rosyjskojęzycznych za nowatorski wkład w rozwój literatury rosyjskiej/rosyjskojęzycznej. 
hitleryzmem, ale w optyce antropologiczno-intelektualnej (w rozumieniu tego terminu $\mathrm{z}$ eseju Tomasza Manna Über die Lehre Spenglers z roku 1924) oraz narodowej i choć „niepatetycznej”, to faktycznie (pod względem rangi treści i formy) wielkiej wojnie ojczyźnianej, tworzonej w horyzoncie ukraińskiego dekolonialnego zwrotu ${ }^{30}$ i być może, jak trafnie zauważył Mychajło Słabosz-

${ }^{30}$ Odwołuję się tu do dekolonialnego zwrotu, lansowanego od lat 70.-80. XX wieku przez intelektualistów latynoamerykańskich, którzy zdecydowanie zdystansowali się i nadal dystansują od dominujących w naukach humanistycznych dyskursów postkolonialnych, hegemonialnie projektowanych przez anglo-amerykańskie i francuskojęzyczne studia kulturowe. Dekolonialiści, do których grona za najbardziej opiniotwórczych powszechnie zalicza się takie postacie, jak: Enrique Dussel, Anibal Quijano, Walter Mignolo, Ramón Grosfoguel, Edgar Lander, Nelson Maldonado-Torres, Arturo Escobar, Fernando Coronil, Catherine Walsh, uważają bowiem, że dyskursy postkolonialne, będąc zakotwiczonymi $\mathrm{w}$ uniwersalnych paradygmatach nowoczesności, kontynuują uniwersalizujące hierarchie odziedziczone $\mathrm{z}$ okresu kolonialnego. Dekolonialiści, dążąc do radykalnej jakościowej zmiany paradygmatów, odcinają się od koncepcji dekolonizacji, czyniąc podstawą swego programu dekolonialność. Dekolonizacja $\mathrm{w}$ ich rozumieniu to stanowiący składową imperialistycznej historii świata zachodniego proces polityczny, który, w swej istocie ukonstytuowany na europocentrycznym projekcie nowoczesności, nie dokonał krytyki kolonialnych podstaw epistemicznych (stąd, zamiast postkolonializmu, proponują oni mówić o postokcydentalizmie). Dekolonialność natomiast to krytyczny punkt widzenia tych, którzy przez ową nowoczesność zostali wykluczeni. Innymi słowy: dekolonialność to autentyczny głos subalternów, „wyklętych ludów ziemi”, by posłużyć się terminologią rodem $z$ Frantza Fanona, którego myśl uważana jest przez intelektualistów dekolonialnych za zwiastuna dekolonialności. Zob. N. Maldonado-Torres, https://www.youtube.com/watch?v=RONFH9Fis0o (5.04.2016); R. Grosfoguel, Decolonial methods, epistemologies of the South and Fanonian philosophy, https://www.youtube.com/watch?v=-x68bK-4rN4 (5.04.2016); tegoż, An Evening With Ramon Grosfoguel - Postcolonial or Decolonial?, https://www.youtube.com/watch?v=3WUZTFIkb_4 (5.04.2016). Dzięki temu myśl dekolonialna, bazująca w swej analektycznej istocie na geocielesnej polityce wiedzy - w odróżnieniu od studiów postkolonialnych, bazujących na wywodzącej się z nowoczesności teo- i egopolityce wiedzy - demonstrują naukowe i polityczne projekty, wpisane w lokalne geograficzne i bio-graficzne podstawy myślenia i poznania w językach, historiach i pamięciach tych grup ludzi, które znajdowały się na skrzyżowaniu/pograniczu imperialnych i kolonialnych różnic oraz doświadczeń (Zob. W. Mignolo, M. Tlostanova, Theorizing From the Border. Shifting to the Geo-Body-Politics of Knowledge, „European Journal of Social Theory” 2006, t. 9, nr 2, s. 205-221). 
pyćkyj, najistotniejszej wojnie Ukrainy za cały czas jej narodowej historii ${ }^{31}$.

Należy dodać, że od początku działań wojennych na Donbasie powstało wiele tekstów, poetyckich, prozatorskich, dokumentalnych czy publicystycznych, poświęconych rozgrywających się tam wydarzeniom $^{32}$ (także Serhij Żadan w 2017 roku wydał nową powieść o wojnie donbaskiej, zatytułowaną Internat). Jednak żaden $\mathrm{z}$ nich nie ma tej głębi refleksji i siły wyrazu, co powieść Po najdłuższe czasy. Albowiem pisarz nie tylko, czy raczej nie tyle, dokonuje próby zdemitologizowania ukraińskich mitów narodowo-kulturowo-społecznych - właściwych zarówno dyskursowi wschodnio-, jak i zachodnioukraińskiemu, ile - co znacznie istotniejsze - na kartach swej powieści kreśli dogłębną egzystencjalną refleksję o śmierci i przemijaniu ${ }^{33}$, osadzoną w nowej dla literatury ukraińskiej wrażliwości na przemoc, strach, cierpienie, ból jednostki/„małego człowieka" wojny - w odróżnieniu od chwały i sławy bohaterów (ZSRR) z socrealistycznych utworów ukraińskich, których wzorcowym przykładem są, należący do sowieckiego literackiego kanonu militarnego, Chorażowie Ołesia Honczara ${ }^{34}$.

Aby właściwie zrozumieć przesłanie płynące $\mathrm{z}$ powieści Rafiejenki, w pierwszej kolejności należy zwrócić uwagę na genealogię

${ }^{31}$ М. Слабошпицький, Велика війна... Украӥна 2014, Ярославів вал, Київ 2016, s. 23.

${ }^{32}$ Zob. Російсько-украӥнська війна в культурі, https://uk.wikipedia.org/wiki/ Російсько-українська_війна_в_культурі (24.04.2017).

33 „Он [роман - A.M.] состоит из двух частей. Первая - сказка для взрослых, а вторая часть - новеллы, которые написаны в реалистической манере. Они написаны о тех людях, которые живут и выживают в Донецке. Это реальные судьбы, которые я знаю. Я не мог писать только реализм, потому что тогда бы мне не хватило дыхания понять и простить какието вещи. Простить не только политикам, но и времени и эпохе. Роман о жизни и смерти: какова специфика жизни и смерти в наши с вами времена”. В. Рафеенко, https://112.ua/interview/sostoyanie-voyny-nastolkozhe-estestvenno-dlya-chelovechestva-v-celom-kak-i-sostoyanie-mira-339234. html (17.02.2017).

${ }^{34}$ Zob. I. Захарчук, Війна і слово. Мілітарна парадигма літератури соціалістичного реалізму, ПВД „Твердиня”, Луцьк 2008. 
tytułu oraz motta, odnoszące się do całego tekstu (każda z trzech części utworu posiada swoje oddzielne motta). Nazwa powieści została zaczerpnięta z 23 (22) Psalmu Dawida, który w biblijnej interpretacji stanowi pieśń ufności w miłość i dobroć Boga. To właśnie ostatnia strofa owego psalmu stanowi pierwsze powieściowe motto: „Tak, dobroć i łaska pójdą w ślad za mną / przez wszystkie dni mojego życia / i zamieszkam w domu pańskim / po najdłuższe czasy”. $\mathrm{Z}$ kolei drugie motto to cytat z poematu Paula Vallery'ego Cmentarz morski, będącego poetycką medytacją rozpiętą między życiem i śmiercią, między bytem a nicością. W charakterze motta Rafiejenko użył ostatnią strofę poematu, rozpoczynającą się od słów „Ku życiu trzeba się zwrócić...”, które odsyłają do napawającego optymizmem niezmiennego triumfu życia nad śmiercią. I wreszcie trzecie motto kieruje czytelnika do ulubionego Rafiejenkowego filozofa, Sokratesa i jego intelektualizmu etycznego, ujętego w myśl „Nikt nie życzy zła”.

Wszystkie trzy motta dowodzą, że powieść Po najdłuższe czasy w pierwszej kolejności odnosi się do uniwersalnych fundamentalnych pojęć etycznych, symbiotycznie koegzystujących w świecie: zła i dobra. Rafiejenko, odrzucając relatywizm moralny, zrodzony z marksistowskiej dekonstrukcji wartości religijnych, opowiada się za teorią moralności o korzeniach zarówno chrześcijańskich, jak i starożytnych, gdzie dobro określa poprawność czynów i zachowań człowieka (zgodność z normami moralnymi — ponad i mimo wszystko). Nieprzypadkowo też pisarz odwołuje się do Sokratesa, który, oprócz problematyki antropologicznej i etycznej, w swej myśli filozoficznej sięgał także po problematykę społeczno-polityczną, krytykując, w duchu naprawczym, zarówno ateńską demokrację, jak i system oligarchiczny, wytykając słabe strony ustrojowe oraz błędy tworzących go instytucji (za co był posądzany o antydemokratyzm) ${ }^{35}$.

Z taką też intencją Władimir Rafiejenko kreuje swojego głównego bohatera - profesora filozofii, zmuszonego przez działania wojenne porzucić pracę na uniwersytecie w mieście $Z$ (jak już pisałam, faktycznie będącego odpowiednikiem realnego Doniecka) i zająć

${ }^{35}$ Zob. K.R. Popper, Społeczeństwo otwarte i jego wrogowie, t. 1, przeł. H. Krahelska, Wydawnictwo Naukowe PWN, Warszawa 1993, s. 212-213. 
się prowadzeniem miejskiej łaźni o znamiennej i nieprzypadkowej nazwie „Piąty Rzym”, odsyłającej do prochanowowskiej koncepcji „Piątego Imperium”, stanowiącej wraz z koncepcją „Ruskiego świata”, jeden z głównych filarów ideologicznych putinowskiego neoimperializmu $^{36}$. Protagonista ów, powszechnie nazywany przez swoich przyjaciół i studentów Sokratesem, jest w utworze nie tylko nosicielem sokratejskiego intelektualizmu etycznego, ale i alter ego samego pisarza, który w jednym z wywiadów telewizyjnych, tak mówił:

Я убежден, что наша жизнь состоит из двух величин. Одна величина активное, социальное, рефлексивное и биологическое проживание жизни. Вторая - человеческая часть: доброта, красота, честь, совесть. Это те вещи, которые, на самом деле, не имеют причины. Это то, что в нас есть человеческого, и мы не существуем, как биологические существа. Я не могу сказать, что совесть - это предмет, на который можно показать, но, тем не менее, это совершенно объективная для меня величина, как и для десятков людей, которых я знаю. Именно в это время обостряется значение этих невидимых величин, которые есть основой человеческой жизни, каждого правильного и единственного человеческого поступания: по доброте, по совести, по милосердию. [...] Мы называемся людьми только потому, что есть в нас вещи невидимые, механизмы, которые вырабатывают доброту, прощение, понимание ${ }^{37}$.

Jak widać, tutaj znów twórca odsłania swą sokratejską naturę, koncentrującą się na człowieku i jego życiu wewnętrznym - duszy jako odrębnym i jedynym wartym uwagi/studiów kosmosie. Sokrates uważał wszak, że dusza jest kwintesencją człowieczeństwa, właściwym „ja” jednostki, które odróżnia go od świata zwierząt, stanowiąc siedzibę cnót (areté). Cnota zaś była dla myśliciela dobrem bezwzględnym, dobrem najwyższym, o które człowiek powinien nieustannie zabiegać i dbać, nie zważając na niebezpieczeństwo

${ }^{36}$ Zob. m.in. A. Проханов, Поступь Русской Победы, Терра, Москва 2012, В. Аверьянов і in., Доктрина Русского мира, https://izborsk-club.ru/10269; С. Баранов, Русский мир: этнологический подход, https://izborsk-club. $\mathrm{ru} / 9435$ (14.06.2016).

${ }^{37}$ В. Рафеенко, „Состояние войны настолько же естественно для человечества, в иелом, как и состояние мира", https://112.ua/interview/sostoyanie-voyny-nastolko-zhe-estestvenno-dlya-chelovechestva-v-celom-kak-isostoyanie-mira-339234.html (17.02.2017). 
i śmierć. Aby móc to czynić, człowiek, w przekonaniu Sokratesa, musiał poznać to, co jest dobre, a co złe, albowiem wiedząc, co jest dobre, człowiek będzie automatycznie postępować dobrze.

I właśnie w tym kluczu Rafiejenko zachęca swego czytelnika, by wraz z nim zagłębił się w meandry duszy ukraińskiej: zarówno jednostkowej, jak i kolektywnej, narodowej. Do takiego odczytania skłaniają dwa kolejne motta do pierwszej części utworu, zatytułowanej Łaźnia, symbolizującej w swej istocie Donbas. Pierwsze motto to myśl Tomasza Venclovy, że „...o narodowości nie stanowi pochodzenie, lecz dobrowolny wybór". Drugie motto natomiast to fragment ludowej pieśni, jaką kobziarz Wołoch śpiewa w poemacie Hajdamacy Tarasa Szewczenki: „Випью чарку, випью другу, / Випью третю на потугу, / П’яту, шосту та й кінець, / Пішла баба у танець”. Rafiejenko, podobnie jak Szewczenko, ale także i Gogol, zwłaszcza jako autor Martwych dusz, piętnuje zło, nie tyle społeczne, ile metafizyczne, prowadzące do martwoty ludzkiej i do martwoty świata (nie na darmo jedna $\mathrm{z}$ nowel powieści nosi tytuł Szkice $z$ martwej natury). Twórca, który nadaje swej powieści podtytuł Miejska ballada, tworzy ironiczny i przerażający w swojej ekspresji tragizmu (o wymownie romantycznym ukraińskim rodowodzie) protest song przeciwko neototalitarnej rzeczywistość okupowanego Donabasu. Został on zamieniony, zarówno przez rosyjskiego agresora, jak i niemałą część autochtonów, w piekło zaludnione przez martwe dusze, które zatrute „noworosyjskim jadem”, nie zważając na fatalne historyczne doświadczenie, znów dały się uwieść rosyjskiemu neoimperialnemu Don Juanowi, jaki tym razem przybrał postać Wolanda/Putina:

Часть 2

\section{Куклы Лизы ${ }^{38}$}

Буду счастлив, если грядущие добродетельные мужи,

стремящиеся проникнуть в корни событий,

найдут здесь, чем развлечь ум, на чем задержать взгляд.

38 Prezentowany tekst $\mathrm{w}$ przekładzie na język polski wejdzie do antologii współczesnej literatury ukraińskiej, która ukaże się w 2019 roku nakładem Wydawnictwa Kolegium Europy Wschodniej (wstęp i red. A. Matusiak) pod tytułem Romans $z$ diabłem. Dziękuję pisarzowi za wyrażenie zgody na publikację niniejszego fragmentu powieści - A.M. 
Лиза открыла глаза и уставилась в темноту высокого потолка.

- Так-так, - прошептала, ощупывая руками пространство вокруг себя. - Гладкое и мягкое - это подушка. А вот гладкое и тяжелое - это одеяло. Одеяло-одеяло страшной ночью танцевало.

Это били по городу тяжелые орудия. На противоположном конце $\mathrm{Z}$ умирали люди. Лиза сквозь забытье чувствовала, как души покидают свои тела, ощущала страх и боль умиравших - и ничего не могла сделать. Ничего. И помочь никому не могла.

Вчера после недолгого перемирия боевики в который раз из жилых кварталов $\mathrm{Z}$ нанесли удары по расположениям правительственных войск. Их орудия работали, перемещаясь, провоцируя ответ. И он не замедлил быть. Украина перемалывала город, врабатывала его в затянувшуюся раннюю весну. Вольно и невольно убивала своих же граждан - заложников русского мира, в этой войне просто хотевших выжить.

Лежа в постели, находясь на грани между сном и явью, которая страшнее любого кошмара, Лиза думала о том, что как раз в последние месяцы многие ранее уехавшие на большую землю возвратились обратно в Z. Им не нашлось места в прекрасном далеке от зоны боевых действий. И этим людям сейчас труднее всего. В эту реку входить надо постепенно. Иначе эмоции могут убить. А они ведь без привычки. Впрочем, большинству не до эмоций. Им бы обеспечить родных и близких. Им бы не показать плачущим детям, насколько они сами перепуганы. Насколько им уже не хочется жить. Но хуже всего тем, кто одинок. Вернувшись в Z, они, на самом деле, сюда так и не возвратились. Застряли где-то между мирами. Кто их теперь вернет?

Вчера Лиза беседовала с Мариной Аркадьевной, профессором филологии, бывшей коллегой Гредиса по университету, проживавшей этажом выше. Эта стройная, вечно молодящаяся дама пять месяцев назад уехала из $\mathrm{Z}$ навсегда. И вот вдруг под самое возобновление боевых действий вернулась. Даже Вересаев, не знавший ее близко, расстроился.

Конечно, ни он, ни Гредис ничего по этому поводу не сказали. Увидев худую седоватую профессоршу рано утром на лавочке возле подъезда, спросили, не нужна ли помощь. Услышав ответ, пошли по своим делам. Работники «Пятого Рима» были в курсе, что в Z некоторые вопросы людям лучше не задавать.

А вот Лиза этого знать не хотела. Марья Ворона, так звалась профессорша между своими, проводив взглядом перегруженный «Опель» Вересаева, подмигнула девушке, смотревшей на нее из окна. Оглянувшись по сторонам, убедилась, что рядом никого более нет, достала маленькую бутылочку коньяка из элегантной женской сумочки Jacques Esterel, сделала глоток и закурила сигаретку. Печально, но светло улыбаясь, смотрела в небо над головой, на деревья, голубей, воробьев и синиц. Думала о том, что вот и они не улетели в Киев, хотя и могли. Пернатые сепаратисты оккупированных территорий.

Лиза выпила стакан чаю и спустилась вниз. Посмотрела на профессоршу изучающе и подсела к ней на лавочку. 
- Зачем вернулась? - спросила сурово. - Почему не осталась в Украине?

- Так нет ее нигде, - охотно улыбнулась бледная, худая, как вобла, Марина и предложила Лизе закурить. - Нет такой Украины, куда можно приехать по собственному желанию.

- Не понимаю! - нахмурилась Елизавета. - А Киев, Львов, ИваноФранковск? Карпаты, в конце концов, Закарпатье?

- Дело в том, подруга, - ответила Ворона, - что Украина - это не территория. Понимаешь?

- Не понимаю!

- А ты понимай, не девочка уже! — внезапно осерчала Ворона. - Головой надо думать, даже если с ней не дружишь.

- И чего тут думать? - скривила губы Лиза.

- Территорию можно заселить кем угодно. И, в общем-то, не важно кем...

- А страну нельзя?

- А страна - это люди. Люди, детка! Не шпалы, не рельсы, не запах креозота, не мелькающие деревца в дремучей, как вечная девственность, украинской ночи. Не суржик проводника, не тамбур, пахнущий черт его знает чем. Не бессонница, лишающая мозг последних остатков смысла. Не расстояние по карте. Не столбики верст. Не стрелки и не светофоры. Не корчмы у заросших тиной прудов. Не ведьмы в этих заведениях, пахнущих медовухой и квасом. И даже не черт, который едет на своей телеге от села к селу, хотя это уже ближе к тому, что я имею в виду, на самом деле.

- С какой целью едет черт от села к селу? - подняла брови Лиза.

- Да с любой! - захохотала Марина Аркадьевна. - Какая у черта может быть цель? Ясно, что не торговля. Впрочем, в советской Украине черт всегда служил чем-то вроде старьевщика. Я застала таких в детстве. Да и кто их тут не застал! Особенно много их было после второй мировой.

- Ты видела черта?

- Думаю, да, - улыбается Ворона. - И не однажды.

- И как он выглядел?

- Лысый кобель. Низковатый, мощный, но не жирный. Мускулистый сатир в хламиде до пят. Похожий на казака Мамая. Впрочем, что такое хламида, точно не известно. Если исходить из интуиций языка, а мы можем рассчитывать только на них, - профессорша строго глянула на Лизу, - это что-то имеющее родство с хламидиями и хламом. Нечто интимно, болезненно старое, подлежащее утилизации. В чем-то подобное греху, наслаждению, тайной страсти, коренящейся в стремлении владеть и жить прошлым, скапливающимся в человеческих мозгах и в предметах быта...

- В старых вещах?

- В старых идеях, поступках, в непригодных для жизни империях, контурных картах с обозначенными на них границами, в знаках различия, письмах и фотографиях... - Ворона щелкнула зажигалкой и жадно затянулась. 
- Ладно, но ты начала о чертях и старьевщиках!

- Да, верно, - Ворона усмехнулась легкому ветерку, подувшему от реки. - Старьевщики столетиями разъезжали по этим землям на засранных лошадях, а потом в одночасье куда-то все подевались. Куда и как отдельная история, и не последнее значение, судя по всему, в ней сыграло КГБ. Но здесь не об этом.

Старьевщики меняли хорошие вещи на хлам, ветошь. На дырявые мешки и пододеяльники, простыни, рубашки, порванные брюки, изжеванные крысами матерчатые туфли, поеденные молью портьеры, папин халат, мамино пальто, бабушкин пиджак, полосатые трусы деда. Верхнюю и нижнюю одежду. Предметы матерчатого быта. Культурный осадок, мягкий, рассыпающийся под пальцами хлам бытия. Все, что осталось от прошлого. Его нечего хранить, незачем над ним дрожать. Его следует вынести и выбросить...

- Но ты хранишь! - замечает Лиза, нахмурившись. - Болеешь этим прошлым, мучаешься им, но все равно продолжаешь беречь!

- Молодец! Именно так! В том-то и дело! - кивает Ворона. - Ты знаешь - это все надо выбросить! Не помнить! Не знать! Не позволять прошлому руководить твоими мыслями и поступками, но ничего не можешь поделать...

- Тебя тяготит, - снова добавила Лиза, — и влечет, скажем, Советский Союз...

- Хотя бы и он, - согласилась Марина. - Может быть, Османская империя, Византия, Рим. Возможно, времена казацкой вольницы, память о которых бурлит в твоей крови. Тебе невмоготу от этих шаровар, сабель, бубнов, табунов за твоим плечом, от криков соплеменниц-украинок, проданных в рабство на невольничьих рынках Средиземноморья, от смрада и стонов, исходящих от убитых турок, татар, цыган, евреев и поляков. Они ведь так и ходят за тобой из сновидения в сновидение последние три столетья. И вот тут приезжает некто на дребезжащем тарантасе и кричит неожиданно молодым и задорным голосом: «Ветошь! Тряпки! Покупаем тряпки! Ба-ра-хло! Бра-хло!».

- Черт кричит задорным голосом? Он же старый?

- Он вечный! - улыбаясь, говорит Ворона. - Потому молодым и задорным! Он кричит свое «барахло», а у тебя все внутри переворачивается!

- Отчего же?

- Понимаешь, - задумчиво пожевала фильтр потухшей сигареты Марина Аркадьевна, - это слово только на письме выглядит просто и обыденно. На самом деле, невыразимо прекрасное брахло тягуче и пенно разливается по округе. Оно свежо и звонко, как майское утро, как лепестки диких яблонь и вишен, устилающие железнодорожный путь жизни, предстоящей самой себе! Бра-хло! Детство, юность, счастливое незнание того, что будет дальше. Родители молодые и здоровые. Тропинки между яблонями свежи и чисты.

- Но как это выглядит? 
- Очень просто. По улице между домами медленно движется телега. Выкладывая на нее хлам прошлого, можно иногда выручить какую-то мелочь. Однако прожитая жизнь приносит устрашающе мало денег, поджимает губы Ворона. - Поэтому чаще ее меняли на новенькие, не знавшие жизни вещи. На детские игрушки, мягкие прекрасные презервативы...

- Презервативы? - удивленно подняла брови Лиза.

- Да, именно, - подтвердила Ворона, - украинский черт всегда имел в телеге заграничные презервативы, и это, безусловно, способствовало развалу Советского Союза сильнее, чем все диссидентское движение вместе взятое. Сначала кондом, а потом уже Солженицын. Но речь и не об этом тоже. Что еще имелось на этой телеге? Много чего. Чай черный байховый, «Королева Марго», церковные свечи, «Протоколы сионских мудрецов», кожаные итальянские туфли - сорок второй размер, «Три мушкетера», молдавский «Кагор», рыболовная леска производства ГДР, французский коньяк, пиво «Жигулевское» - четыре бутылки, бронзовые увесистые, хотя и топорно сделанные, канделябры, пресс-папье, наливные ручки, прищепки, венгерская резина, клей, красная гуашь. В холщовых мешках сахар, соль, спички.

Старые вещи охотно меняли на новенькие веники, чтобы мести ими дом. Веники были холодные и желтые, а вещи, оставляемые старьевщику, - жалкие, мятые, часто изъеденные молью и непрестанными квантовыми скачками. Но старьевщика нисколько не смущало это обстоятельство. Он собирал прошлое в мешки, не гнушаясь ничем. Служитель смерти, рабочий сцены Театра полураспада, философ и торгаш.

- Ты рассказываешь страшные вещи, - заметила Лиза.

- Скорее, печальные, - возразила Ворона. - Но давай вспоминать дальше. Что лежало на телеге старьевщика в разные годы?

- А что, ассортимент менялся?

- Да, от месяца к месяцу, от эпохи к эпохе. Хорошо бы подробно описать, что за граждане подходили к телеге, что именно оставляли на ней и что, улыбаясь улыбками людей, сделавших удачное приобретение, относили в свои жилища. Стоило бы, вероятно, кому-нибудь из тех, кто не знал разочарований и потерь, подытожить все это. Оглянуться, приосаниться, но тут же загрустить. Сплюнуть вязкой похмельной слюной в грязноватый тающий снег, закурить, внезапно заплакать. Кто-то должен создать список вещей, достойных упоминания, и перечислить их в правильном порядке, который бы сам по себе, как список кораблей, приоткрыл бы завесу непознанного. Нужно разодрать холст смерти и залить его желтой акварелью вечной памяти, светом, текущим из сияющей пустоты в наши несчастные, в сущности, жизни...

- Ты отвлекалась, - немного подумав, сказала Лиза. - Расскажи, каков был черт из себя?

- Старик, говорю, но скорее - мужчина в самом соку, - призналась Ворона. - Его обожали наши шумные любвеобильные бабы. Сатир, 
хотя скорее - кентавр, он со своей телегой то и дело оставался у них на ночь.

- То есть речь шла именно о сексе?

- Никак иначе! — пожала плечами Ворона. - Его излюбленной позой была поза сзади. Грубо говоря, он имел их по-собачьи.

- Кого имел по-собачьи? - покраснела Лиза.

- Да всех. - Профессорша задумалась. - Впрочем, в этом есть скорее нечто лошадиное. В любви он - кентавр, сильный, грубый и нежный до невозможности. Хам-хам! Конь с яйцами. Изящнейший мужчина. Мустанг. Дикое, в принципе, существо.

- Как это выглядело со стороны?

- Весьма, кстати, соблазнительно. Он был виртуоз в своем роде и мог склонить к этому почти любую женщину из тех, что ему улыбались, принося и выкладывая на его телегу прошлое, настоящее, будущее, свою верхнюю, а в особенности нижнюю одежду. К некоторым он подбирался в тот момент, когда они готовили угощение.

- Что, прямо на кухне? - удивилась Лиза.

- Ну конечно, - Ворона сделала маленький глоток, - на летней кухне, озаренной светом из открытой печи, овеянной запахами того, что варилось, жарилось, парилось и пеклось. Гусь с рисом и изюмом, баранья нога с винной подливой, заливное, курица с яблоками и курагой, пироги с мясом щуки и судака, сладкая кукурузная каша подается с абрикосовой настойкой и пирожками с луком. Печеная свинина в кисло-сладком соусе с холодной анисовкой и моченой калиной. Квашеная капуста в меду, утка с орехами и черносливом. Запахи трав - укропа, базилика, петрушки, мелиссы, мяты. Кориандр и кардамон, черный молотый перец, имбирь, цедра лимона, корица. День, осененный стремительно облетающими белейшими лепестками вишен, слив, яблонь, кустов сирени и черемухи. В зависимости от того, в какой двор украинский черт по самую глотку нынче въехал своей аккуратной ладной телегой.

- Но как это начиналось? - слегка покраснев, спросила Лиза. - Дело в том, что я пока еще имею не так много соответствующего опыта. Он, безусловно, уже появляется. Однако львиная доля познаний в этой области остается, так сказать, более теоретической. Мне хотелось бы оживить чем-то схемы и формулы, трактаты, фолианты, чертежи, устные наставления любовников древности. Не могла бы ты поделиться некими подробностями, если, конечно, они свежи в твоей памяти?

- Охотно, подруга! Отчего бы их не освежить? - кивнула Ворона и, расправив крылья, снова сложила их, принялась неспешно чистить перышко за перышком черным блестящим клювом, продолжая говорить. - Сначала старьевщик рассказывал нечто веселое, не имеющее прямого отношения к искусству любви. Хозяйка фаршировала рыбу. Ветерок веял, а солнце клонилось в закат. В какой-то момент он клал широкую сильную ладонь женщине на талию, свободной рукой приобнимал и принимался то и дело оглаживать плечи и животик, прижимаясь все 
теснее к женским ягодицам тем самым местом, спрятать которое он не мог и не желал.

- Не мог и не желал?

- Верно! - подтвердила Ворона. - Говорил и терся, хохотал и прижимался, и покусывал мочки ушей, и затылочек, пахнущий сладким потом. Лизал длинным шершавым языком пушок на спинке, благо сарафаны у баб прошлого времени свободные, как балахоны ку-клукс-клана. Ловко касался длинными узловатыми пальцами пунцового цвета женской груди, большим и указательным пальцами слегка растирал соски, будто непрожаренные зерна кофе. Вновь прижимался и гладил, вдыхал и облизывал. Женщина чувствовала ладони, жесткую бородку, шумное дыхание, неразборчивые сладкие слова и едва понимала, о чем говорит сей остроумный сатир, ибо ей досаждал немолчный прибой черной крови в ушах, шум в голове и любовная дрожь, озноб и предчувствие, которые иной раз слаще всего остального.

- И вы так просто отдавались ему?

- Нет, почему же, - передернула плечами Марина Аркадьевна. Женщина пыталась противостоять, но, в сущности, не в силах была понять, к чему данный философ клонит. А когда, наконец, понимание приходило, тот, кого скрыть невозможно, был тесно прижат к ее ягодицам. Они же, в свою очередь, были обнажены и полураскрыты, как створки раковины, моллюска, возможно, перловицы, что, безусловно, обещало беспрепятственный доступ ко всему, что течет, трепещет и жаждет битвы.

- Но как же неугомонному сатиру удавалось выполнять это так ловко, что женщина потом и вспомнить не могла, как на ее голове оказалась ее же юбка? Как входил в нее старьевщик?

- Не утаим и этого, - кивнула Ворона. - Рывками, упруго, сильно, но нежно. Она податливо расставила ноги и легла набухшей ноющей грудью на разделочный стол. Щека ерзает по столу туда и сюда, в фокус зрачка попадает то ощипанный петух с полураскрытым мертвым скандальным глазом, то букет мальвы в росе, которую старьевщик наломал ранним утром у околицы поселка.

- Но как становилось сие возможно? - всплеснула руками Лиза. Они ведь, считай, незнакомы?

- Вопрос, и немалый, - кивнула Марина Аркадьевна. - Но внимания достойно и иное чудо. Как он умудрялся закидывать их ноги себе на плечи?

- То есть?

- Иная толстушка, - Ворона сделала маленький глоток, - думать не думала, что окажется способной на такой кульбит. Ведь не спортивная же она какая-нибудь гимнастка, из тех, какими бывают увлечены не только слабые, но даже сильные мира сего. А вот же, посмотри ж ты! Качаются в воздухе женские ножки, периодически касаясь затылка древнего сатира, но возможно, просто кентавра. Его затылок порос жесткой курчавой седоватой порослью, будто виноградом «изабелла» и «шардонне». Каж- 
дый раз, когда пятки касаются винограда, баба кричит и стонет. Вглядись в бессмысленную мутную поволоку, коей подернуты ее глаза, посмотри, как стекает прозрачная слюнка из уголка рта, как хрипит она горлом, играет лоном, горит животом и кишками и как, утихомирившись, ослепительно улыбается черт, когда закуривает после любви, глядя в закатное доброе солнце.

- А потом?

- Потом он становился нежен. Просил повторить. Но девушка, одумавшись, крутила динамо. Заставляла его делать разные забавные штуки. Черт озадачивался, а порой и влюблялся! Бывало даже, бросал промысел, становясь подкаблучником и дураком! Она дарила ему любовь, а он помогал избавиться от ненужного прошлого. - Марина Аркадьевна улыбнулась. - Вот это и есть страна! А ты мне говоришь - территория. Роман с чертом - вот это и есть Украина! Любовь с метафизикой, с бытием, со смертью! А отнюдь не границы, прочерченные неизвестно кем и непонятно с какими целями.

- Что-то ты больно подробно рассказываешь, - Лиза утерла испарину. - И как-то я потеряла связь с предыдущим разговором. Ты говорила, что в Украину приехать нельзя...

- Помолчи, дай об этом кончу, - махнула рукой Ворона. - От этих неразборчивых, но в целом, конечно, избирательных связей рождались задорные чернявые дети с наглыми глазами. Все как один - хитрецы, знавшие ответы на любые вопросы. Например, кто быстрее съест человечьи внутренности - волк или лисица. Четное ли количество звезд на небе или же нет. Кто управляет миром? Кто таков мастер имен? Что лучше Смит иль Вессон? Боже мой! - Марина Аркадьевна даже прослезилась. - Калибр десять целых и шестьдесят семь сотых миллиметра, ёмкость барабана шесть патронов, длина ствола восемь дюймов, патрон центрального воспламенения, ускоренная перезарядка.

В них обильно текла польская, греческая и еврейская кровь. Они говорили по-арабски лучше, чем на родном литовском или белорусском. Знали языки птиц. Жили, сколько хотели. На турнике возле здания вечерней школы номер пятьдесят два крутили солнце, держась за перекладину одной рукой. На охоте с замначальником областного УВД по пьяной лавочке с пятидесяти метров попадали в пятак. Умаявшись от жизни, выпивали два ведра горилки, закусив рыжиком, салом или плотвой. Об украинцах, живущих на этих территориях, говорили всякое. Например, что они никогда не болеют и никто из них никогда не умрет...

Где-то за прудами раздался страшный взрыв. Было такое ощущение, что земля немного просела под ними, дома покачнулись и даже воздуха в пространстве стало ощутимо меньше. Профессорша с испугом посмотрела на Лизу и, будто очнувшись, замолчала.

- Слушай, - напомнила Лиза, - ты стала говорить, что в Украину попасть нельзя. Давай, растолкуй, о чем ты. Я так понимаю, это и есть твоя история? Страсть как хочется послушать. 
Марина Аркадьевна щелкнула зажигалкой, помолчала, разглядывая игру света и тени на листьях липы.

- Сто лет пытаюсь людям втолковать, - Марина Аркадьевна пожала плечами. - Украина - это не границы, не таможня, не религиозный бэкграунд. Не карты языковых предпочтений. Не водоразделы и не тектонические плиты. Это люди, млять! Люди и еще раз люди! Они и есть культура! К их предкам из столетия в столетие приезжал один и тот же старьевщик! И берег всегда один и тот же Бог! Вот тебе и вся идентичность.

- Ну хорошо, - кивнула Лиза, - пусть люди. И что, я теперь не могу приехать во Львов?

- Как сказать... - хмыкнула Ворона.

- А я вот думаю, что могу! - мечтательно проговорила Лиза. - Надо только взять у Сократа немного денег, надеть синее с маками платье, купить бутылку минеральной воды и упоминавшихся ранее презервативов. Говорят, в Галиции люди страсть как охочи к сексу с выходцами из восточных регионов. Любить, конечно, не станут, но в постель уложат. Верно ли, Марина Аркадьевна?

- Был у меня по молодости оттуда один любовник, - вздохнула Ворона. - То ли дьяк, то ли пономарь. Это, случаем, не одно и то же? Никогда в этом не разбиралась. Да и встречались мы всего пару раз, когда я во Львов приезжала на научные конференции. Так вот, он открыл мне разницу между православными и греко-католиками. Хочешь знать, в чем она заключается?

- И в чем же?!

- Православные страдают страстью еды и питья, деньги любят, хамы и жадноваты...

- Ваты-ваты, - эхом повторила Лиза.

- Я ж и говорю, жадноваты, - кивнула Аркадьевна. - Епископ у нас на «Майбахе» в собор на литургию едет, а пузо протоирея подобно сталеплавильной печи. Народ же при этом живет бедно...

- А греко-католики?

- В тех страсти много! - убежденно кивнула Марина. - Это их губит! Слишком горячи. Неимоверные любовники. Но при этом любят только себя, что бы ни говорили. Талантливы неимоверно, предельно эгоистичны, селяне. Умны, страшно суеверны и мнительны. Властолюбивы. Живут в патефонной трубе, через которую Бог глядит на Восток. На свет выходить не спешат. Хитрые, упрямые, умирают трудно, а сгорают быстро, но оставляют после себя долгий след.

- Так и что из этого следует? - нахмурилась Лиза. - Нельзя просто сесть в поезд и приехать в Украину?

- Хочешь знать, на что можно рассчитывать? - покачала головой Ворона. - Я тебе скажу, на что. Ты можешь приобрести железнодорожный билет на территории, свободные от оккупации. Но дело в том, что Украина и территории, свободные от оккупации, - две большие разницы. Марина Аркадьевна спрятала пачку сигарет, к которой Лиза так и не притронулась, в сумочку. 
- По-твоему, получается, - нахмурилась Лиза, - попасть в Украину в принципе невозможно?

- Ну почему же? - пожала плечами Марина. - Вот моим девочкамколлегам, Анне и Зине, повезло. Украина их накормила, напоила, дала одежду, надежду и устроила на работу.

- А тебя?

- А меня сначала ограбили на украинском блок-посту по дороге на поезд. Ну, то такое, - она пожала плечами, - деньги - пыль. Но потом на вокзале в Киеве какая-то зараза сумочку с документами потянула. Я ж рассеянная кобыла, - Марина Аркадьевна печально улыбнулась. Так и осталась без диплома, паспорта, без всего.

- И что?!

- А ничего, - улыбнулась Ворона. - Ни жилье толком снять, ни на работу устроиться. Сразу даже не поняла, насколько это серьезно! Потому и не сдалась. - Марина Аркадьевна хрипло засмеялась. - Пожила по ночлежкам, походила по высоким кабинетам, потрясла мозгами, поелозила соплями, хотела инферно разжалобить. Глупая я тетка, несмотря на то, что до седин дожила. Деньги растратила, вещи распродала. Но в результате все равно вернулась в Z! - Она достала из сумочки шоколадную конфету и протянула девице. - Раз сигареты - не твое, Елизавета, угощайся, так и быть! Это сакральный «Рошен», у меня еще найдется. Две конфеты заменяют стакан кокаина.

- Спасибо! - поблагодарила Лиза.

- Вместо Украины, - продолжила Марина Аркадьевна, - нашла я в Киеве советских мудаков. Сидят себе в высоких кабинетах. И рефлексы у них сосущие. Крови им хочется украинской, другой брезгают. Им все равно, на каком языке говоришь, им красненькое подавай. Ориентируются! - щелкнула клювом Ворона. - Знают, что нация - не язык, но сердце. Как завидят настоящее, так и сосут его кровь. Лижут, фыркают, морщатся от удовольствия. Забавные твари. Все до одного, кстати, сторонники войны до победного конца и при этом пацифисты.

- И что ж теперь? - нахмурилась Лиза.

- А что теперь? - повторила Ворона, устало посмотрев на солнце. Восстановить в этой жизни ничего нельзя. Кроме того, территории здесь оккупированные. Сижу на солнышке, сигаретки покуриваю, зарабатываю алкоголизм.

- Значит, не повезло?

- Откуда это значит? - Марина скептически посмотрела на Лизу. К везению или невезению произошедшее не имеет никакого отношения! Запомни, когда мы не мыслим точно, нами играет Путин! Но в Украину нам дорога закрыта!

- Не понимаю, а коллеги твои как туда добрались?

- Если уж тебе и впрямь хочется, скажу. - Ворона придвинулась ближе. - Но пусть это останется между нами. Можно на тебя рассчитывать в этом вопросе? 
- Само собой! - кивнула Лиза. - У меня диагноз. Таким, как я, не верят!

- Это аргумент, - кивнула Марина Аркадьевна. - Ладно, слушай. Дело в том, детка, что Анна и Зина, соответственно, французский романтизм и Германия эпохи Просвещения, погибли.

- Как погибли?! - тряхнула головой Лиза.

- Слышала, месяца три назад боевики из минометов обстреляли поезд?

- Что-то такое было, - Лиза неуверенно кивнула.

- Вот в этом поезде они ехали из $\mathrm{Z}$ в Киев.

- Так как же ты говоришь, что они работают и все такое?

- А вот в этом, - Ворона оглянулась по сторонам и подсела к собеседнице поближе, - и состоит главнейшая тайна этой войны. - Из Z в Украину попасть можно, только приняв смерть от рук боевиков! От рук матрешек цвета хаки!

- Принять смерть, чтобы попасть в Украину?! - закусила губу Лиза. - То есть как это?

- А как угодно! - охотно уточнила Марина Аркадьевна и несколько раз резко и протяжно каркнула. - Тебя могут расстрелять, взорвать, отравить, сжечь, забить в подвалах бывшего СБУ. Можешь сама собой с голоду подохнуть, благо здесь это не так трудно, как кажется из Киева. Смерть, гарантирующая искомый результат, выходит при насильственном повешенье, при остановке сердца во время допроса, да мало ли...

- Не понимаю, - нахмурилась Лиза. - Обожди, ну вот, скажем, умер ты, и что потом?

- А потом, - Ворона снова победно заорала, подпрыгнула на черных жестких лапах и, широко расставив крылья, сделала круг над головой Лизы, - сразу оказываешься возле древней липы у самого фундамента Десятинной церкви. Эта липа Марко Поло помнит! И тебя она встретит с радостью. А можешь очнуться на Щековице. Вот так, как я сейчас, попивая коньяк, в ус не дуя да сигаретки покуривая. Некоторые после смерти находят себя на углу Крещатика и Прорезной. Стоишь такой себе, Марина Аркадьевна счастливо засмеялась, - в одной руке мороженое, в другой - пиво. Солнышко светит. Направо - митинг против кондитера. Налево - митинг в поддержку его сладкого. Народ ведь там, что бы ни думал, понимает - альтернативы ему нет. Сине-желтая столица, плюрализм и богатство мнений. Пьяный мент ссыт на брусчатку у спуска в метро, и прямо тут же парень на волынке исполняет. И так это все правильно, так чудесно! А главное, до кнайп-клуба рукой подать, где Жадан через час стихи про Марию читать станет.

- То есть ты умер, но при этом Крещатик, Жадан и волынка на углу Прорезной и Крещатика... И ты стоишь живой?

- Нет, интересно, а какой же еще? - закаркала Ворона, усевшись на ветку черемухи прямо над головой Лизаветы. - Конечно, живой! И ты живой, и Жадан, и кондитер, изюма с орехами ему в печень, пусть будет сладким тысячу лет. И это не кончится уже никогда. 
Правда, при этом ты не помнишь, как добирался в Киев, и очень неясно, что было до этого, и, главное, зачем. Вообще последние недели перед смертью останутся в памяти очень условно. Подробностей - никаких. Все в сизо-красном тумане. Будто дымкой подернуто. Но вообще ты помнишь, что в Украину собирался, что близкие тебя отговаривали, потому как в Киеве нацизм и шоколадно-ореховое мракобесие.

- Страшно умирать! - заметила Лиза.

- Очень страшно, - птица склонила голову набок, - но зато, если ты попал в Киев, во Львов или, скажем, в Станислав именно после смерти, то куда 6 ни пошел, везде встретит тебя Украина. Понимаешь? Куда ни пойдешь, а тут она! - Ворона внезапно всхлипнула, каркнула печально и протяжно, заплакала крупными прозрачными слезами. - Но только после смерти!

- Не плачь, Марина Аркадьевна! - укоризненно покачал головой Лиза. - Пьяные это слезы.

- Так если 6 трезвые, разве бы я каркала тут перед тобой? - Ворона тяжело взмахнула крыльями, обернулась нетрезвым романо-германским филологом, пожала плечами, сделала еще пару затяжек и яростно затушила сигарету. - Ну вот, а я осталась жива. Живой попала в Киев, поэтому и Киев был мне не Киев, и встретилась с мудаками. Так что, детка, это вопрос сложный, кому повезло, мне или им. Скорее всего - никому. Просто у каждого своя судьба.

- Ты сказала, что у Анны и Зины все хорошо, - спросила Лиза, рассматривая конфету, - и работа, и надежда, и одежда?

- Все чудесно! Официантками работают в «Макдональдсе» и о другой карьере даже не помышляют.

- Ну как же может быть одновременно, чтобы и погибли, и все так чудесно?

- Дура, что ли? - Аркадьевна вздохнула и тяжело поднялась с лавки.

- В жизни только так и бывает. Кто-то мертвый бургеры киевлянам делает. А кто-то, как мы здесь все, вроде живой, но больше не человек.

- А кто мы тогда?

- Инструмент шантажа, статистическая погрешность.

Pisarstwo Władimira Rafiejenki jest w najnowszej literaturze ukraińskiej jedynym, jak do tej pory, jaskrawym przykładem „kolonialnej rany" ${ }^{39}$, która, choć pisana po rosyjsku, staje się potężnym

39 Figurę retoryczną „kolonialna rana” używam w znaczeniu, jakie nadaje jej Gloria Anzaldua, tj. „translacyjnej” tożsamości (la mestiza), będącej hybrydowym 
ukraińskim głosem (niczym Munchowski Krzyk), wydobywającym się z samych trzewi Donbasu; głosem, który w geście dekolonialnej dialogiczności domaga się radykalnego procesu przepracowania bolesnych traum trapiących dzisiejszą Ukrainę, jej społeczeństwo, kulturę, historię, pamięć, mentalność, wreszcie tożsamość. Ów horyzont dekolonialnej dialogiczności jest niezwykle istotny, albowiem otwiera on nowe możliwości na krytyczną/twórczą/ emancypacyjną transformację ukraińskiego dziedzictwa kulturowego i ukraińskiej tożsamości kulturowej, która $\mathrm{z}$ obiektu badań, jakim jest ona w optyce postkolonialnej, może stać się znaczącym i mówiącym własnym językiem podmiotem, zapowiadającym nowe odniesienia $\mathrm{w}$ stosunku do otaczającej rzeczywistości oraz wytwarzanie nowej, własnej i oryginalnej w swej subiektywności wiedzy o sobie samej ${ }^{40}$. Co więcej, sądzę, że przyjęcie dialogicznej/ granicznej (w rozumieniu tego terminu przez Waltera Mignola ${ }^{41}$ ) optyki epistemologii dekolonialności w sposób optymalny oddaje w perspektywie synchronicznej i diachronicznej (po)kolonialną istotę tożsamościowej sytuacji kultury ukraińskiej, przynależnej od swego zarania do cross-kulturowego i cross-epistemicznego geo-obszaru granicy Okcydentu i Orientu; istotę, która pozwala uchwycić symbiotyczny proces kolonizowania kultury ukraińskiej zarówno przez kolonizatora wschodniego - rosyjskiego/radzieckiego, jak i przez kolonizatora zachodniego - polskiego (dziś przez globalizujący Zachód) oraz jednocześnie również przez rodzime elity intelektualne i polityczne. A zatem strategia taka umożliwia wykazanie, że ukraińska tożsamość kulturowa konstytuowała się jako wypadkowa kolonializmu zewnętrznego i wewnętrznego we

splotem kulturowego dziedzictwa kolonizatorów i kolonizowanych; tożsamości, która nie usiłuje zniwelować owych sprzeczności bądź na siłę ich zhomogenizować, lecz zachowując je, nadać im wymiar inspirującej dekolonialnej strategii emancypacyjnej. Zob. G. Anzaldua, Borderlands/La Frontera. The New Mestiza, Aunt Lute Books, San Francisco 1999.

${ }^{40}$ Zob. F. Fanon, Wyklęty lud ziemi, przeł. H. Tygielska, Państwowy Instytut Wydawniczy, Warszawa 1985, s. 214.

${ }^{41}$ Zob. W. Mignolo, La idea de América Latina. La herida colonial y la opción decolonial, Estudios Filológicos, Barcelona 2007. 
wszystkich kluczowych obszarach kolonialności: nie tylko polityczno-ekonomicznej, ale także władzy, wiedzy, bycia, pamięci czy gender. W sytuacji politycznej, w jakiej obecnie znajduje się Ukraina, trzeba pamiętać o tym, że aby zakładane reformy mogły zostać przeprowadzone $\mathrm{z}$ sukcesem, to właśnie owe sfery, "zarządzające” procesami myślowymi, w pierwszej kolejności winny zostać poddane dekolonialnej autodekonstrukcji. Nie od dziś wiadomo, że władza w obszarze wytwarzania podmiotowości to fundamentalna sfera, w której rozgrywa się walka polityczna, co znakomicie opisuje Foucaultowska formuła wiedzy/władzy, a na środkowo-wschodnioeuropejskim gruncie literackim choćby Czesław Miłosz w Zniewolonym umyśle, Vladimir Nabokov w Zaproszeniu na egzekucję, z kolei w literaturze ukraińskiej już w latach 20. XX wieku Mykoła Chwylowy w antyutopijnej Sanatoryjnej zonie (1924) oraz nie tyle anty-, ile właśnie auto-dekolonialno-detotalitarnych pamfletach, których podsumowanie stanowił zakazany na ponad 70 lat tekst Ukraina czy Małorosja.

Агнешка Матусяк

РАЗМЫШЛЕНИЯ ПО ПОВОДУ ДОНБАССКОГО ПОВЕСТВОВАНИЯ

В УКРАИНСКОЙ КУЛЬТУРЕ И ЛИТЕРАТУРЕ

С ТОЧКИ ЗРЕНИЯ ХХІ ВЕКА

Резюме

В настоящей статье речь идет о политическом, культурном и психическом несходстве Донбасской области с остальными частями Украины. Автор представляет неповторимость этого региона как результат сложной и противоречивой истории, а также итог постоянных общественных, экономических и этнокультурных процессов колониального и тоталитарного характера. Все это становится поводом гибридной идентичности здешних жителей. В дальней части больше места уделяется творчеству двух писателей - украиноязычного Сергея Жадана и русско-украиноязычного Владимира Рафеенко. 
Agnieszka Matusiak

\section{REFLECTIONS ON THE DONBASS NARRATIVE \\ IN UKRAINIAN AND RUSSIAN CULTURE AND LITERATURE \\ FROM THE $21^{\text {ST }}$ CENTURY'S POINT OF VIEW}

\section{Summary}

The article is devoted to political, cultural and mental diversity of Donbass from the rest of Ukraine. The author shows the uniqueness of this region as a result of a complex and contradictory history, as well as the effect of permanent social, economic and ethnocultural processes of a colonial and totalitarian character. This is the reason for the hybrid identity of local residents. Later on, more space is devoted to the work of two writers - Ukrainian-speaking Serhiy Zhadan and Ukrainian-Russian-speaking Vladimir Rafeenko. 